\title{
图 \\ Distribution and population dynamics of ticks (Acari: Ixodidae) infesting sheep in Sennar State, Sudan
}

\author{
M.S. MOHAMMED ${ }^{1 *}$ and S.M. HASSAN²
}

\begin{abstract}
MOHAMMED, M.S. \& HASSAN, S.M. 2007. Distribution and population dynamics of ticks (Acari: Ixodidae) infesting sheep in Sennar State, Sudan. Onderstepoort Journal of Veterianry Research, 74: 301-306

A cross-sectional survey of ticks infesting sheep was conducted in Sennar State, Sudan. A total body collection of ticks was carried out at five localities Sennar town, Singa, Dinder, Abu Naama and Um Banein on two types of Desert sheep (Watish and Ashgar) on two farms at each locality at two monthly intervals for one year starting July 2002 to May 2003. Four tick genera and eight species were identified. They were Amblyomma lepidum, Hyalomma anatolicum anatolicum, Hyalomma truncatum, Rhipicephalus (Boophilus) decoloratus, Rhipicephalus camicasi, Rhipicephalus evertsi evertsi, Rhipicephalus guilhoni and Rhipicephalus muhsamae. A significant $(P \leq 0.05)$ seasonal pattern of activity was observed for $A$. lepidum and $R$. guilhoni with peak activity occurring during rainy seasons. The highest mean number of ticks $(7.26 \pm 0.58)$ was recorded at Abu Naama, while the lowest mean $(3.61 \pm 0.31)$ was recorded in Sennar. Watish type sheep carried significantly $(P \leq 0.05)$ more ticks than Ashgar type.
\end{abstract}

Keywords: Population dynamics, Sudan, ticks

\section{INTRODUCTION}

Ticks and tick-borne diseases (T\&TBDs) are major constraints to livestock improvement in many parts of the world especially in the tropics (Walker, Bouattour, Camicas, Estrada-Peña, Horak, Latif, Pegram \& Preston 2003). T\&TBDs of sheep and goats are less well studied than those of cattle. Nevertheless, small ruminants are able to acquire resistance to most tick species and principles of enzootic stability and the need to preserve it are similar to those in cattle (Tatchell 1997).

\footnotetext{
* Author to whom correspondence is to be directed

1 Faculty of Veterinary Science, University of Nyala P.O. Box 155, Nyala, Sudan

2 Faculty of Veterinary Medicine, University of Khartoum, Private P.O. Box 3288, Khartoum, Sudan

Accepted for publication 2 April 2007-Editor
}

The Sudanese tick fauna comprises 68 tick species (Osman 1978; Jongejan, Zivkovic, Pegram, Tatchell, Fison, Latif \& Paine 1987), many of which have veterinary importance. Hoogstraal (1956) conducted the first systematic studies on ticks in the Sudan. Osman (1978) confirmed 20 tick species infesting domestic animals in Darfur State, Western Sudan, while Jongejan et al. (1987) reported 24 species infesting cattle and wildlife along the Blue Nile and the White Nile rivers.

Recently Salih, Hassan, El Hussein \& Jongejan (2004) identified 12 species infesting cattle at different localities in the Northern, Central, Western and Eastern Sudan. The distribution of T\&TBDs has changed, due to the extensive animal movement, deforestation, desertification and the establishment of large mechanized agricultural schemes (Hassan \& Salih 2005). Studies on the seasonal occurrence of the various developmental stages of ticks are of 
great significance in the epidemiology of tick-borne diseases and in planning appropriate tick control measures (Norval, Andrew \& Meltzer 1991). The objectives of this study were to elucidate the distribution and seasonal population changes of ticks infesting sheep in Sennar State, Sudan.

\section{MATERIALS AND METHODS}

\section{Study area}

The study was conducted at five localities in Sennar State during the period July 2002 to May 2003.

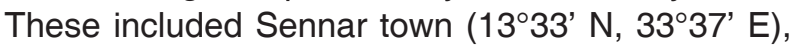

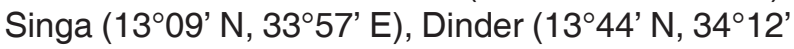
E), Um Banein (13 $\left.04^{\circ} \mathrm{N}, 33^{\circ} 57^{\prime} \mathrm{E}\right)$ and Abu Naama $\left(12^{\circ} 44^{\prime} \mathrm{N}, 34^{\circ} 08^{\prime} \mathrm{E}\right)$ (Fig. 1). Meteorological data were recorded throughout the study period.

\section{Tick collection}

Total body collections of ticks infesting sheep were carried out on two farms at each locality at two monthly intervals for one year (July 2002 to May 2003). Ten adult sheep of different types were randomly chosen on each farm. These animals were of different coat colour and different sex. Debilitated sheep and pregnant ewes were excluded. All visible ticks were collected from the entire body surface using a pair of blunt metal forceps. The collected ticks were preserved in vials containing $70 \%$ ethyl alcohol. Animal type, coat colour, locality, farm and date of collection were recorded. Ticks were identified under a dissecting microscope using the description of Hoogstraal (1956), Walker, Keirans \& Horak (2000) and Walker et al. (2003). The ticks recovered from each animal were recorded according to genera, species, sex and developmental stages.

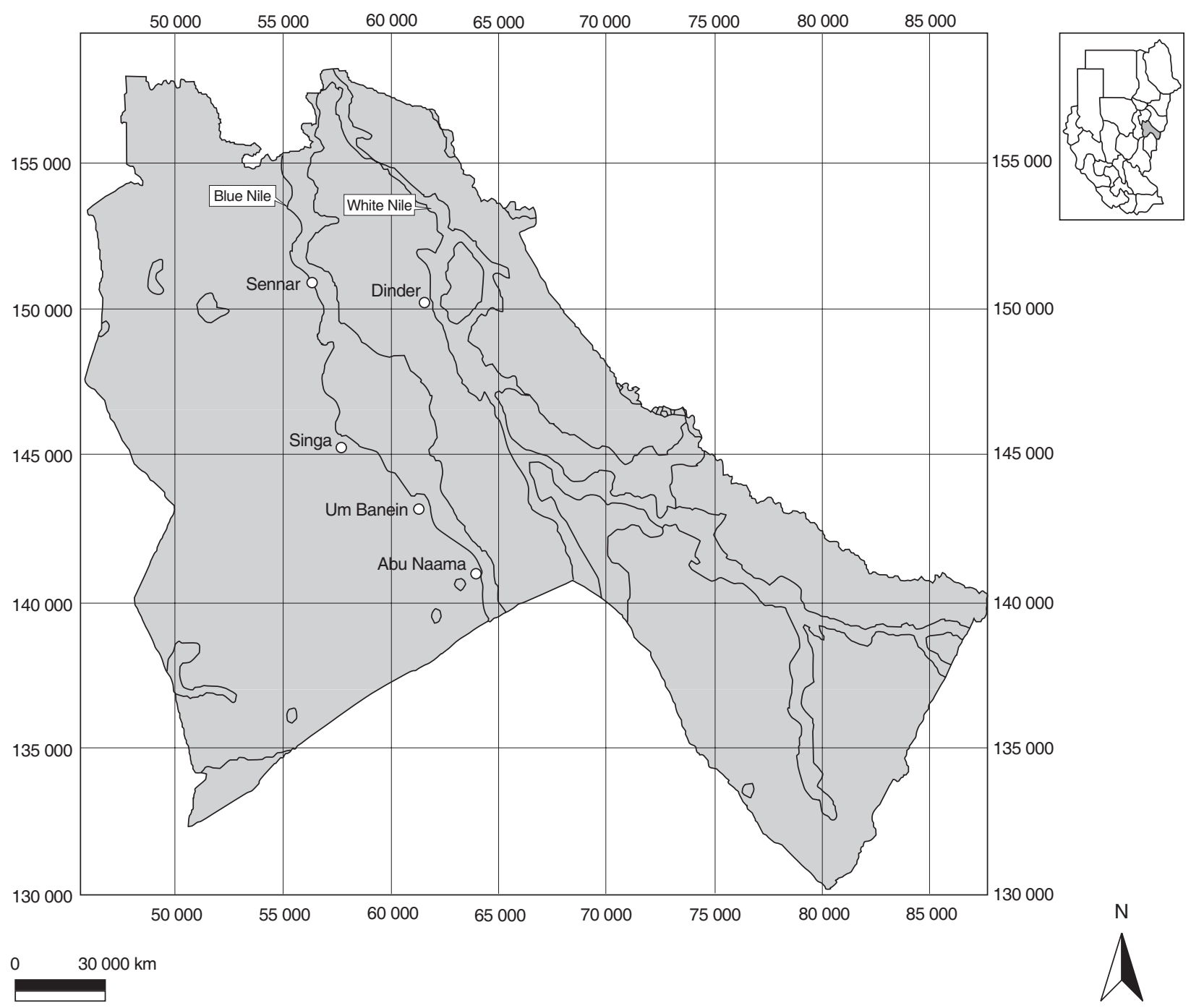

FIG. 1 Map of Sennar State showing localities at which samples were collected 


\section{Statistical analysis}

Data collected on ticks infesting sheep at different locations were subjected to appropriate general linear model (GLM) procedure of statistical analysis system (SAS) package. The SAS was used to perform analysis of variance (ANOVA) while mean separations were performed using Ryan- Einot- GabrielWelsch (REGW) multiple range test (Day \& Quinn 1989). Correlation analysis was carried out to relate tick abundance to meteorological data.

\section{RESULTS}

Three tick genera and eight species were identified. These were Amblyomma lepidum, Hyalomma anatolicum anatolicum and Hyalomma truncatum, Rhipicephalus (Boophilus) decoloratus, Rhipicephalus camicasi, Rhipicephalus evertsi evertsi, Rhipicephalus guilhoni and Rhipicephalus muhsamae.

The mean total numbers of ticks per sheep at different localities are summarized in Table 1. The highest mean $(7.26 \pm 0.58)$ was recorded at Abu Naama, while the lowest mean $(3.61 \pm 0.31)$ was recorded in Sennar town. Seasonal occurrence of adult ticks revealed that the peak $(2.75 \pm 0.43)$ of $A$. lepidum occurred in November and the lowest $(0.47 \pm 0.13)$ record was in January. The peak $(1.66 \pm 0.30)$ of R. e. evertsi occurred in March and the lowest (0.18 $\pm 0.05)$ collection was in September. The highest abundance $(7.84 \pm 0.57)$ of $R$. guilhoni was in September while the lowest was in May (Table 2). Table 3 summarizes the mean numbers of adult ticks per head of sheep according to sheep type.

The tick species found in small numbers were $R$. (B.) decoloratus, $H$. a. anatolicum, $H$. truncatum, $R$. camicasi, and $R$. muhsamae. Table 5 shows information on their geographic distribution and total count.

The correlation analysis between the mean total numbers of the three most numerous tick species and mean monthly maximum and minimum ambient temperatures, relative humidities, and total monthly rainfall are shown in Table 4. Data on geographic distribution, seasonal occurrence and correlation with meteorological parameters are given for each tick species separately as indicated below.

\section{Amblyomma lepidum}

This tick species was present at all localities. The highest mean $(2.37 \pm 0.19)$ total body collected ticks was recorded at Um Banein and the lowest $(0.16 \pm$ 0.05 ) in Sennar (Table 1). There was a clear pattern of seasonality of $A$. lepidum being significantly abundant in November and the least abundance was in January and July (Table 2). There was no significant difference $(P \geq 0.05)$ between $A$. lepidum infestation and sheep type (Table 3 ). On the other hand, there was no significant correlation between $A$. lepidum occurrence and mean monthly maximum ambient temperature. Similarly, there was no apparent correlation between the occurrence of this tick and mean monthly minimum atmospheric temperature. Furthermore, there was no well-defined relationship between $A$. lepidum occurrence and total monthly rainfall nor mean monthly relative humidity (Table 4).

\section{Hyalomma a. anatolicum}

This xerophilic tick was collected in low numbers during the study period. The highest number was recorded in Sennar, followed by Dinder and only three males and one female were found at Um Banein (Table 5).

\section{Hyalomma truncatum}

Only two males were collected at Abu Naama during the dry season (March and May) (Table 5).

\section{Rhipicephalus (B.) decoloratus}

This tick was recorded in very low numbers during the rainy season (July and September) at Um Banein, Abu Naama and Singa (Table 5). All the ticks collected were females.

\section{Rhipicephalus e. evertsi}

Rhipicephalus e. evertsi was collected at all localities. It was highly abundant in Singa and Sennar while the lowest record was at Um Banein (Table 1). There a clear pattern of seasonality of this tick being abundant in the dry season of March and May and the lowest record was in the wet season of September (Table 2). There was no significant correlation $(P \geq 0.05)$ between $R$. e. evertsi abundance and sheep type (Table 3 ). There was a strong positive correlation between $R$. e. evertsi abundance and mean monthly maximum atmospheric temperature, and mean monthly minimum atmospheric temperature (Table 4). There was also a significant negative correlation between $R$. e. evertsi abundance and mean monthly relative humidities, but the correlation was not significant with total monthly rainfall (Table 4).

\section{Rhipicephalus guilhoni}

This species was present at all localities being highly abundant in Dinder and Abu Naama (Table 1). 
Dynamics of ticks (Acari: Ixodidae) infesting sheep in Sennar State, Sudan

TABLE 1 Mean ( \pm SE) numbers of ticks collected from sheep at different localities in Sennar State, Sudan during 2002-2003

\begin{tabular}{|l|l|l|l|l|}
\hline Localities & A. lepidum & R. e. evertsi & R. guilhoni & Total no. of ticks \\
\hline Um Banein & $2.37 \pm(0.19)^{\mathrm{a}}$ & $0.27 \pm(0.06)^{\mathrm{b}}$ & $3.51 \pm(0.25)^{\mathrm{a}}$ & $6.14 \pm(0.38)^{\mathrm{a}}$ \\
Abu Naama & $1.78 \pm(0.33)^{\mathrm{a}}$ & $0.72 \pm(0.13)^{\mathrm{b}}$ & $4.76 \pm(0.47)^{\mathrm{a}}$ & $7.26 \pm(0.58)^{\mathrm{a}}$ \\
Dinder & $1.03 \pm(0.17)^{\mathrm{b}}$ & $0.58 \pm(0.16)^{\mathrm{b}}$ & $5.43 \pm(0.50)^{\mathrm{a}}$ & $7.05 \pm(0.53)^{\mathrm{ab}}$ \\
Singa & $0.55 \pm(0.11)^{\mathrm{bc}}$ & $1.43 \pm(0.33)^{\mathrm{a}}$ & $3.71 \pm(0.28)^{\mathrm{b}}$ & $5.68 \pm(039)^{\mathrm{b}}$ \\
Sennar & $0.16 \pm(0.05)^{\mathrm{c}}$ & $0.84 \pm(0.16)^{\mathrm{ab}}$ & $2.62 \pm(0.26)^{\mathrm{b}}$ & $3.61 \pm(0.31)^{\mathrm{c}}$ \\
\hline
\end{tabular}

Number of observations $=120$ at each locality

Means $( \pm \mathrm{SE}$ ) followed by the same letter in each column are not significantly different at the $5 \%$ level based on Ryan's $Q$ test (REGWQ)

TABLE 2 Mean ( \pm SE) numbers of ticks collected from sheep in Sennar State, Sudan in various months during 2002-2003

\begin{tabular}{|l|l|l|l|l|}
\hline Month & A. lepidum & R. e. evertsi & R. guilhoni & Total no. of ticks \\
\hline July 2002 & $0.90 \pm(0.19)^{\mathrm{c}}$ & $0.87 \pm(0.14)^{\mathrm{bc}}$ & $5.60 \pm(0.48)^{\mathrm{b}}$ & $7.37 \pm(0.50)^{\mathrm{b}}$ \\
September 2002 & $1.53 \pm(0.20)^{\mathrm{b}}$ & $0.18 \pm(0.05)^{\mathrm{c}}$ & $7.84 \pm(0.57)^{\mathrm{a}}$ & $9.55 \pm(0.61)^{\mathrm{a}}$ \\
November 2002 & $2.75 \pm(0.43)^{\mathrm{a}}$ & $0.35 \pm(0.10)^{\mathrm{c}}$ & $3.98 \pm(0.49)^{\mathrm{c}}$ & $7.08 \pm(0.49)^{\mathrm{b}}$ \\
January 2003 & $0.47 \pm(0.13)^{\mathrm{c}}$ & $0.21 \pm(0.10)^{\mathrm{c}}$ & $3.48 \pm(0.23)^{\mathrm{c}}$ & $4.16 \pm(0.29)^{\mathrm{c}}$ \\
March 2003 & $0.77 \pm(0.23)^{\mathrm{bc}}$ & $1.66 \pm(0.30)^{\mathrm{a}}$ & $1.67 \pm(0.17)^{\mathrm{d}}$ & $4.10 \pm(0.40)^{\mathrm{c}}$ \\
May 2003 & $0.65 \pm(0.13)^{\mathrm{bc}}$ & $1.33 \pm(0.34)^{\mathrm{ab}}$ & $1.46 \pm(0.16)^{\mathrm{d}}$ & $3.44 \pm(0.39)^{\mathrm{c}}$ \\
\hline
\end{tabular}

Number of observations $=100$ in each month

Means $( \pm$ SE) followed by the same letter in each column are not significantly different at the $5 \%$ level based on Ryan's $Q$ test (REGWQ)

TABLE 3 Mean ( \pm SE) numbers ticks collected from different sheep types

\begin{tabular}{|l|l|l|l|l|l|}
\hline Sheep type & No. of sheep examined & A. lepidum & R. e. evertsi & R. guilhoni & Total no. of ticks \\
\hline Watish & 438 & $1.08 \pm(0.12)^{\mathrm{a}}$ & $0.83 \pm(0.11)^{\mathrm{a}}$ & $4.40 \pm(0.21)^{\mathrm{a}}$ & $6.32 \pm(0.27)^{\mathrm{a}}$ \\
Ashgar & 162 & $1.43 \pm(0.22)^{\mathrm{a}}$ & $0.58 \pm(0.12)^{\mathrm{a}}$ & $2.94 \pm(0.21)^{\mathrm{b}}$ & $4.96 \pm(0.32)^{\mathrm{b}}$ \\
\hline
\end{tabular}

Means $( \pm$ SE) followed by the same letter in each column are not significantly different at the $5 \%$ level based on Ryan's $Q$ test (REGWQ)

TABLE 4 Correlation analysis between tick species infesting sheep in Sennar State and meteorological data

\begin{tabular}{|c|c|c|c|c|}
\hline \multirow{2}{*}{ Tick species } & Temperat & & \multirow{2}{*}{ Relative humidity } & \multirow{2}{*}{ Total rainfal } \\
\hline & Max & Min & & \\
\hline $\begin{array}{l}\text { A. lepidum } \\
R . \text { guilhoni } \\
R . \text { e. evertsi }\end{array}$ & $\begin{array}{r}-0.02 \mathrm{~ns} \\
-0.44^{* * *} \\
0.20^{* * *}\end{array}$ & $\begin{array}{l}0.07 \mathrm{~ns} \\
0.05 \mathrm{~ns} \\
0.10^{* * *}\end{array}$ & $\begin{array}{r}0.06 \mathrm{~ns} \\
0.52^{* * *} \\
-0.13^{* * *}\end{array}$ & $\begin{array}{l}-0.02 \mathrm{~ns} \\
0.33^{\star \star \star} \\
-0.02 \mathrm{~ns}\end{array}$ \\
\hline Total ticks & $-0.29 * * *$ & 0.12 *** & 0.40 *** & 0.25 *** \\
\hline
\end{tabular}

*** $P<0.001$

ns not significant

TABLE 5 Total numbers of ticks (male/female) infesting sheep in very low numbers at different localities in Sennar State in 2002/ 2003

\begin{tabular}{|l|l|l|l|l|l|}
\hline Locality & B. decoloratus & H. a. anatolicum & H. truncatum & R. camicasi & R. muhsamae \\
\hline Um Banein & $0 / 3$ & $3 / 1$ & $0 / 0$ & $8 / 2$ & $1 / 0$ \\
Abu Naama & $0 / 3$ & $0 / 0$ & $2 / 0$ & $10 / 3$ & $1 / 0$ \\
Dinder & $0 / 0$ & $19 / 13$ & $0 / 0$ & $3 / 2$ & $2 / 0$ \\
Singa & $0 / 1$ & $0 / 0$ & $0 / 0$ & $3 / 2$ & $5 / 2$ \\
Sennar & $0 / 0$ & $73 / 30$ & $0 / 0$ & $\mathbf{2 7 / 1 1}$ & $1 / 0$ \\
\hline Total ticks & $\mathbf{0}$ & $\mathbf{9 5 / 4 4}$ & $\mathbf{2 / 0}$ & $\mathbf{1 0 / 2}$ \\
\hline
\end{tabular}


This tick showed a significant pattern of seasonality with a clear peak in September but drastically decreased in the dry season of March and May (Table 2). Watish type of sheep carried significantly more R. guilhoni than Ashgar type (Table 3). There was a strong negative correlation between $R$. guilhoni abundance and mean monthly maximum atmospheric temperature, but there was no significant correlation between the abundance of this tick and mean monthly minimum atmospheric temperature (Table 4). The largest burdens of $R$. guilhoni coincided with the rainfall period and increased relative humidity (Table 4).

\section{Rhipicephalus camicasi}

This species was collected in low numbers throughout the study period at all localities. The highest number was reported at Abu Naama during dry seasons (November, January, March and May) (Table $5)$.

\section{Rhipicephalus muhsamae}

This West African tick species was present in very low numbers during the dry seasons (November, January and March) at all localities (Table 5).

\section{DISCUSSION}

Since the major study of Hoogstraal (1956) on ticks in the Sudan, and that of Jongejan et al. (1987) of the Blue and White Nile ecosystem, no systematic research has been conducted on the distribution and seasonal occurrence of ixodid ticks in Sennar State. The present study yielded eight tick species infesting sheep at five localities (Table 1). This finding is similar to those previously reported in Darfur, Kordofan and along the banks of the White and Blue Nile rivers (Osman 1978; Osman, El Hussein, Neima \& Abdulla 1982; Jongejan et al. 1987).

Tick numbers on sheep were relatively low. The highest mean total number of ticks was recorded at Abu Naama, while the lowest mean was reported in Sennar. This may be attributed to the effect of occasional chemical acaricide treatments administered during the wet season. There was a clear pattern of seasonality for A. lepidum and R. guilhoni. Karrar, Kaiser \& Hoogstraal (1963) reported similar seasonal effects for $A$. lepidum in Kassala. In Kordofan the number of $A$. lepidum reached a peak between August and September in the rainy season (Osman et al. 1982). Jongejan et al. (1987) reported no pattern of seasonality for $A$. lepidum or any other tick species in Northern Sudan. They attributed this to the irregular intervals between collections. Amblyomma lepidum occurs in a wide variety of climatic zones, from temperate (highland) to savannah, steppe and desert, but it is most common in arid habitats with 250-750 $\mathrm{mm}$ rainfall (Walker et al. 2003). Rhipicephalus guilhoni was the predominant species throughout the study period in all locations. Osman (1978) and Osman et al. (1982) during their studies in Darfur and Kordofan provinces found that the predominant ticks belong to the $R$. sanguineus group. Rhipicephalus guilhoni can exist under relatively dry conditions in areas with $500-750 \mathrm{~mm}$ annual rainfall, and even in some places with only 250-500 $\mathrm{mm}$ in the southern parts of the Sahel (Walker et al. 2003). Walker et al. (2000) reported that $R$. guilhoni was probably the most common and widely distributed tick on livestock in Mali and was regarded as the predominant tick species in the Sahelian area of Senegal.

The present study revealed that peak numbers of $R$. e. evertsi were present during the dry seasons with lesser numbers recorded during the rainy seasons. However, Walker et al. (2000) have pointed out that R. e. evertsi can also be commonly present in habitats receiving between $1200 \mathrm{~mm}$ and $2600 \mathrm{~mm}$ of annual rainfall. Theiler (1950, cited in Hoogstraal 1956) suggested that increasing aridity limits the distribution of this species and that critical rainfall level lies between $250 \mathrm{~mm}$ and $375 \mathrm{~mm}$ annually. In the current study $R$. camicasi was found in low numbers in all locations. It is a tick of north-eastern Africa (Walker et al. 2000), and had been reported in the Sudan for the first time by Jongejan et al. (1987). In Egypt it occurs in stone and gravel desert regions (Walker et al. 2000). In Ethiopia and Somalia it is apparently the most active tick species during the dry season (Pegram, Clifford, Walker \& Keirans 1987). Osman (1978) and Osman et al. (1982) collected small numbers of this tick species during their studies in Western Sudan. Similar to previous studies carried out in the area Boophilus decoloratus was found in very small numbers throughout the study period (Jongejan et al. 1987; Salih et al. 2004). This species occurs in regions with savanna and temperate climates, typically in grasslands and wooded areas used as cattle pasture. It tends to be absent in the drier regions in countries such as Namibia, South Africa and Botswana (Walker et al. 2003). Similar to previous studies $R$. muhsamae was found in small numbers (Jongejan et al. 1987; Osman, 1978; Osman et al. 1982). With the exception of western Uganda, Rwanda and Burundi this species has been recorded across Africa from Senegal to 
Ethiopia (Walker et al. 2000). It occurs mainly at altitudes of less than $1000 \mathrm{~m}$ in woodland with a mean annual rainfall of $800 \mathrm{~m}$ or less (Walker et al. 2003).

Hyalomma a. anatolicum is adapted to areas with Mediterranean and steppe climates in North Africa, and to steppe and desert climates elsewhere in its extensive range in the region. It extends as far south as the northern parts of central Sudan (Walker et al. 2003). However, the presence of this tick at Um Banein indicates that the limit of this species distribution has changed and that it has moved southwards to latitude $13^{\circ} \mathrm{N}$ (FAO 1983; Jongejan et al. 1987; Salih et al. 2004). Hyalomma truncatum was recorded in very low numbers at Abu Naama during the dry season. This species had not been recorded along the Blue Nile (Jongejan et al. 1987; Salih et al. 2004). However, Salih et al. (2004) recorded it in Western Sudan and along the White Nile. This species is adapted to dry habitats and is commonest in desert, steppe and savanna climatic regions. It is common in the Afrotropical zoogeographical region and is generally restricted to areas south of the Sahara (Walker et al. 2003)

Watish type sheep were found to be significantly ( $P$ $<0.05)$ more heavily infested with ticks than Ashgar type sheep. This finding may be attributed to the coat colour of the animal as Hassan (1997) has found that tick burdens may be correlated with host coat colour. He found that cattle with white coats predominantly carried significantly more ticks than those with brown coats, while black-coated cattle carried the least number of ticks. He suggested that ticks picked up by animals with black or brown coats die or leave the host before attachment, because of the raised temperature of the host environment generated by the dark coat colour.

\section{ACKNOWLEDGEMENTS}

We are grateful to Prof. I.G. Horak, Department of Veterinary Tropical Diseases, Faculty of Veterinary Science, University of Pretoria for generously supplying information on the identification of Rhipicephalus species.

\section{REFERENCES}

DAY, R.W. \& QUINN, G.P. 1989. Comparison of treatment after analysis of variance in ecology. Ecological Monographs, 59: 433-463.

FAO. 1983. Ticks and tick-borne diseases control. The Sudan: Tick ecology and tick control. Technical report, no. 1, AG: CP/SUD/024/DEN. Rome: Food and Agricultural Organization of the United Nations.
HASSAN, S.M. 1997. Ecological studies on Rhipicephalus appendiculatus and Amblyomma variegatum (Acari: Ixodidae): drop-off rhythms, development, survival, and seasonal population dynamics. Ph.D. Thesis Kenyatta University, Kenya.

HASSAN, S.M. \& SALIH, D.A. 2005. Factors affecting geographical distribution of livestock ticks in the Sudan. Insect Science and its Application. (In press.)

HOOGSTRAAL, H. 1956. African Ixodoidea. 1. Ticks of the Sudan (with special reference to Equatoria Province and with preliminary reviews of the genera Boophilus, Margaropus and Hyalomma). Department of Medical Zoology, United States, Naval Medical Research Unit No. 3. Research report NM 005 050.29.07.

JONGEJAN, F., ZIVKOVIC, D., PEGRAM, R.G., TATCHELL, R.J., FISON, T., LATIF, A.A. \& PAINE, G. 1987. Ticks (Acari: Ixodidae) of the Blue and White Nile ecosystems in the Sudan with particular reference to the Rhipicephalus sanguineus group. Experimental and Applied Acarology, 3:331-346.

KARRAR, G., KAISER, M.N. \& HOOGSTRAAL, H. 1963. Ecology and host-relationship of ticks (Ixodoidea) infesting domestic animals in Kassala Province, Sudan, with special reference to Amblyomma lepidum Donitz. Bulletin of Entomological Research, 54:509-522.

NORVAL, R.A.I., ANDREW, H.R. \& MELTZER, M.I. 1991. Seasonal occurrence of the bont tick (Amblyomma hebraeum) in the southern lowveld of Zimbabwe. Experimental and Applied Acarology, 13:81-96.

OSMAN, A.M. 1997. Major tick-borne diseases of sheep and goats in the Sudan. Parasitologia, 39:143-144.

OSMAN, O.M. 1978. Preliminary notes on the distribution of ticks (Acarina: Ixodidae) in Darfur Province, Sudan. Bulletin of Animal Health and Production in Africa, 26:329-333.

OSMAN, O.M., EL HUSSEIN, A.M., NEIMA, A. \& ABDULLA, H. S. 1982. Ecological studies on ticks (Acarina: Ixodidae) of Kordofan Region, Sudan. Bulletin of Animal Health and Production in Africa, 30:45-53.

PEGRAM, R.G., CLIFFORD, C.M., WALKER, J.B. \& KEIRANS, J.E. 1987. Clarification of Rhipicephalus sanguineus group (Acari, Ixodoidea, Ixodidae). I. R. sulcatus Neumann, 1908 and R. turanicus Pomerantsev, 1936. Systematic Parasitology, 10:3-26.

PUNYUA, D.K. \& HASSAN, S.M. 1992. The role of host management in tick population changes on Rusinga Island, Kenya. Experimental and Applied Acarology, 14:61-65.

SALIH, D.A., HASSAN, S.M., EL HUSSEIN, A.M. \& JONGEJAN, F. 2004. Preliminary survey of ticks (Acari: Ixodidae) on cattle in northern Sudan. Onderstepoort Journal of Veterinary Research, 71:319-326.

TATCHELL, R.J. 1997. Sheep and goats management. Parasitologia, 39:157-160.

WALKER, J.B. \& OLWAGE, A. 1987. The tick vectors of $C$. ruminantium (Ixodoidea, Ixodidae), genus Amblyomma and their distribution. Onderstepoort Journal of Veterinary Research, 54:353-379.

WALKER, J.B., KEIRANS, J.E. \& HORAK, I.G. 2000. The genus Rhipicephalus (Acari, Ixodidae): A guide to the brown ticks of the world. Cambridge: Cambridge Academic Press.

WALKER, A.R., BOUATTOUR, A., CAMICAS, J-L., ESTRADAPEÑA, A., HORAK, I.G., LATIF, A.A., PEGRAM, R.G. \& PRESTON, P.M. 2003. Ticks of domestic animals in Africa: A guide to identification of species. Bioscience reports. 